\title{
E-Government and Social Media Sites: The Role and Impact
}

\author{
Rawan T. Khasawneh", Emad A. Abu-Shanab \\ Information Technology College, Yarmouk University, Irbid, 21163, Jordan \\ *Corresponding Author: rawan.khasawneh77@yahoo.com
}

Copyright (C) 2013 Horizon Research Publishing All rights reserved.

\begin{abstract}
The Internet became an indispensable part of people's lives because of the significant role it plays in the way individuals interact, communicate and collaborate with each other. Also, the recent evolvements in social media (such as blogs, websites and other social networking tools like Facebook, Twitter and Googleplus) tempted governments around the world to join these sites in a try to benefit from the new way of communication and interaction provided by such tools. On the other hand, social media has become a platform that is easily accessible to anyone with Internet access which makes governments that joined these sites have the capacity to rebuild the relationship with their citizens and increase the level of citizens' engagement and participation. In order to achieve the goal of this paper, the Jordan e-government page on Facebook is taken as a case study. Several page insights indicates that there is a good level of engagement by citizens, where they interact positively with the posts published by the page through making a like, comment, share, answering a question or just see the page. Also, it is noticeable that the insights show that the page fan base is mostly comprised of men between 25 and 34.
\end{abstract}

Keywords E-government, Social Networks, Facebook, Page Insights, Jordan, Case Study

\section{Introduction}

Information and communication technologies (ICTs) have become not only a ubiquitous part of people's life but also a loved one especially that the growing use of such technologies, and specifically the Internet, has significant impact on the way individuals interact, communicate and connect with each other. Also, the development of social media (SM), like blogs, websites and other social networking tools like Facebook, Twitter and Googleplus, makes governments around the world join these sites in a try to benefit from a new way of communication. On the other hand, social media has become a platform that is easily accessible to anyone with Internet access which makes governments that joined these sites have the capacity to rebuild the relationship with their citizens and increase the level of citizens' engagement and participation.

These days governments, the legitimate party managing people's lives, have tried to incorporate ICTs into their work, processes, services to enhance people's quality of life and improve public service and performance. E-government is the new paradigm that influences and get influenced by many factors in our life: social issues, infrastructure capacity, and governmental factors [1].

The wide usage of social media sites and tools by people, private sector firms and public organizations, makes government want to think carefully on how it can benefit from such usage in rebuilding its relationship with citizens, increasing their participation and engagement level. Such issue is important as e-government websites are perceived as public sites and wait for citizens to visit them. On the contrary, social networks (SN) are sites where people interact, and entering such sites can bring governments and their citizens closer [2].

This paper will focus on the ways through which e-government can benefit from the services provided by social networks to gain real time engagement with citizens, to adopt new way of interaction with individuals, and to get more insights on citizen's perceptions and opinions on various issues. It will show how governments can simply improve their presence on social networks. Also, it will try to assimilate the literature view on e-government 2.0 concept. The rest of the paper will be organized as the following: The next section summarized related work. Then the data and related analysis will be presented, where a detailed description of the issue will be elaborated. Finally conclusion is provided.

\section{Literature Review}

In the last few years, social media has become a platform that is easily accessible to anyone with Internet connection, and the favorite communication channel for a large number of people. Such shift made governments think of utilizing such channel in a strategic way to benefit from social media 
in conducting much of their business and interact with citizens in an effective, efficient, and a much-loved way.

\subsection{An Overview of Social Media}

Social media became a platform that is widely used by people in order to converse and communicate with each other online easily and in a cheap way [3]. Harris and Rea [4, p.137] defined social media (web 2.0) as "a perceived second generation of Web development and design that facilitates communications and secures information sharing, interoperability, and collaboration on the World Wide Web" [4]. Based on this definition, it is obvious that the major function of $\mathrm{SN}$ is communication and interaction, where e-government historically evolved into two major stages that focus on information sharing and communication [5][6].

One of the benefits of social media is that it gives a new way of communication in which people can share information within their special profile and view content and information in other connected profiles within bounded environment [7]. SM is shifting people from being content readers to become content generators and publishers, and it became an important feedback mechanism through which people have two-way information flow [8][9][10]. Diverse types of content can be obtained from and shared on social media sites such as news, advertisements, documents, videos and music [11], where users can enjoy both uploading their own content or share others and disseminate content throughout their network.

As a result of the fast growing usage of social media sites, a variety of social media tools with special and attractive functions are available which focus on getting people attention and attract them to join these sites. Based on that, social media sites can be classified into the following four main categories based on the different functions provided [12]:

a) Directories that serve resume writing functions with rating capabilities performed by clients and colleagues. LinkedIn is a good example of this type of network.

b) Communication channel that provides information and text dissemination functions on an ongoing and up-to-date basis; a good example of such type of networks are Twitter and all types of blogs (like Blogger).

c) Communities and rating sites that serve less formal interactions within closed sites and can be used for events promotion; a good example of this type of function are Facebook and the fan pages available on it.

d) Archiving and sharing sites that used for storing and sharing videos, documents and slides with active feedback channels; a good example of this function are YouTube and slideshare.

Social media is not only an IT application but also it is an important communication tool that affects how individuals interact, communicate and connect with each other and enables them to share text, video and audio files. Moreover, social media provides individuals with an easy way to access information they need and build a relationship they want through a huge human network available through it [13]. Here is an overview of some social media sites reviewed from more than one source.

Facebook: is one of the fast growing social networks sites; launched in 2004 with easy to use interface and wide range of features [14][15]. Facebook has several personal applications where people can create their individual accounts in order to communicate and share information with their friends, family members and coworkers more efficiently. Also, it has a professional application where businesses and organizations can create their fan pages that enable them to have a two-way interaction with their customers through a feedback and active communication channel. Facebook will make organization's dream come true in reaching millions of customers easily and in minimum cost and time [14]. Das and Sahoo proclaimed that Facebook has the first rank in the list of the ten most popular social networking sites in the world with M550 estimated unique monthly visitors [16].

Twitter: is another example of the fast growing social networks sites; launched in 2006 with an open communication capability that enables people to create free accounts through which they can communicate with each other using short text messages or "tweets" with a maximum of 140 characters [17][18]. Twitter can be described as a large repository of information and as another form of electronic word-of-mouth (e-WOM) that can be used for socio-political purpose and for marketing purpose [18]. Das and Sahoo indicated that Twitter has the second rank in the list of the ten most popular social networking sites in the world with M95.8 estimated unique monthly visitors [16].

MySpace: is one of the general-purpose social networking sites [19]; launched in August 2003 by Tom Anderson the CEO of an Internet company called eUniverse [20]. Das and Sahoo indicated that MySpace has the third position in the list of the ten most popular social networking sites in the world with M80.5 estimated unique monthly visitors [16].

LinkedIn: is one of the business-oriented social networking sites that are mainly used for professional networking [14][15]. It was founded in December 2002 and then launched in May 2003 with an executive form of social networking [14]. Each member of LinkedIn site would fill hisher profile that looks like a resume, with several professional credentials such as work history, current work experiences and professional expertise [14][19]. Das and Sahoo indicated that LinkedIn is ranked fourth in the list of the ten most popular social networking sites in the world with M50 estimated unique monthly visitors [16].

Other sites: Other social networking sites are available on cyberspace such as Ning, Tagged, Friendster, Hi5, Meetup, MyYearbook, and many others. Each of the previously mentioned websites has its special and unique features and options that differentiate them from each other [16][21].

\subsection{E-Government and Social Networks}

E-government can be defined as "government use of 
information and communication technologies to offer for citizens and businesses the opportunity to interact and conduct business with government by using different electronic media such as telephone touch pad, fax, smart cards, self-service kiosks, e-mail/Internet, and EDI" [22, p. $30]$. And it can be classified into several categories based on whom it provides services and benefits. Such categories range from citizens, public agencies, social and political organizations, businesses, employees and non-profit organizations. Government-to-Citizen (G2C), Citizen-to-Government (C2G), Government-to-Business (G2B), Business -to-Government (B2G), Government-to-Employee (G2E), Government to-Government (G2G), and Government-to-Nonprofit (G2N) are all examples of e-government categories [23].

Social media has a significant impact on the way governments are doing their business and how they perform. Governments need to be more interactive and reach citizens where they are and where they feel more comfortable. Also, social media represents a strategic opportunity that should be cautiously managed to better engage individuals, businesses and public organizations [13]. When a government decides to join social media sites, several important factors should carefully be considered; governments need to be careful not to start this activity by making Facebook or Twitter account or fan page and stop at point. Governments need to become an active user of such sites through the provision of timely, ongoing and up-to-date information and also through building this new interactive long-term relationship with citizens and businesses [3].

Atari, Stewart-Weeks and McCalla presented social media as an opportunity that will help governments to become more transparent by providing citizens with better service and information access, opening an active communication channel with them, and finally, empowering citizens and making them more involved [2]. Also, if governments use such sites effectively and efficiently, it will open doors for citizens to become more influential and active participant in the world they live in. In terms of E-participation, social media provides new ways of communication through which governments can deliver any message or news they want more effectively and quickly. Citizens can participate in online conversations on public issues with their local or national governments which will result in more open, transparent and interactive relationship between citizens and their governments [2].

In order to have such relationship with citizens, governments should think carefully on how they can manage their social media sites and how such channel can be used effectively. Managing social media sites can be done using different approaches; a good example is usually used by businesses to manage their social media appearance. The "Four R" approach is based on the following four main actions: Review, focusing on knowing and monitoring what people said online; respond, to make sure that this is an active channel of communication; record, posting rich and high quality content; and redirect, enabling people to benefit from similar situation by redirecting them to others with similar issues or problems. So governments should think carefully on how they can benefit from these approaches in a more effective and easy way in order to get as much as they can from their appearance on social media sites [24].

It is important for governments to have a presence on social media sites in order to build a high level of people trust especially if governments use social media to provide citizens with an active information channel to ensure that governments not only listen or monitor the process but also respond. Also, social media sites give governments an opportunity to take the advantage of using more creative and innovative ways in communicating with citizens and making effective use of the valuable resources available on such sites and outside its control [13].

The literature introduced three types of citizenship regardless of the level of use of technology or any appearance on social media sites. The three types of citizenship are: a personally responsible citizenship which describes citizens who act responsibly in their communities by doing things such as recycling. Second, the participatory citizenship that describes citizens who are active member of society and participate in its improvement efforts. Finally, the justice oriented citizenship that refers to citizens who are responsible for the assessment of political, social and economic structure.

On the other hand, Richards indicated that E-government wants to replace these citizenship types with new types through leveraging the use of technology and social media sites. Such utilization of technology leads to what is called "digital citizenship", which can be classified into three types: the first type is a personally responsible digital citizenship that uses electronic mail instead of paper mail and benefits from government's appearance on social media sites in order to communicate and access real time information. The second type is a participatory digital citizenship that benefits from online discussion forums through social media sites to organize recycling, law obeying and many other activities. The third type is a justice oriented digital citizenship that prefers to participate in online discussions of public issues through social media sites [25].

Abdallah and Khalil presented a list of key domains where E-government can utilize and benefit from web 2.0 services. Following is a brief description of each domain [26]:

- Regulation in which governments can benefit from the direct and open engagement with their citizens in order to enhance not only the governmental role in controlling and monitoring services but also the citizens role in calling for needed regulations from the government. New Zealand police initiative is an example of such experience, where they implemented a wiki that enables citizens to leave their comments and suggestions towards drafting new policing acts.

- Collaboration through which governments can enhance their internal and external interaction by utilizing web 2.0 available services.

- Public engagement which will be the strategic goal behind 
joining social network sites; this key domain area is divided into two main sections: political participation and service provision. Political participation can be enhanced by using several web 2.0 services such as blogs and YouTube. For example, Barak Obama usage of social networks in his presidential campaign in the American presidential election in 2008 enabled him to reach young voters. Service provision which leverages citizen's role in monitoring the delivery and quality of governmental services using web 2.0 available services such as wikis, blogs and mash-up maps.

Also, Kuzma introduced three main categories of benefits that governments can have from using web 2.0 technologies and tools. These three main categories are: Efficiency that implies obtaining increased output with minimum resources. Second, user's convenience, which indicates that a user can search and access what he needs anytime and from anywhere. Finally, citizen's involvement that would increase citizen's participation levels in the democratic process [27]. E-government can also use a wide range of available web 2.0 technologies and tools such as using blogs to communicate with public, RSS feed for work coordination purposes and wikis for internal sharing of expertise and information [28].

\subsection{Toward E-government 2.0}

E-government 2.0 is an emerging concept and new paradigm that focuses on transforming the static and rigid structure of government services that represents the traditional industrial age model to more dynamic and interactive one that represents knowledge revolution age model through the effective use of innovative technologies that will improve the quality of services provided and make government become more open and transparent. E-government 2.0 also transforms the way that governments operate internally and externally with immense shift towards interactive user component. On the other hand, E-participation seems to be not only the core of E-government 2.0 but also it is a key driver for its growth by focusing on three important dimensions of E-participation that can be enhanced through using web 2.0 tools under E-government 2.0 initiatives. These three dimensions are: E-information, E-consultation and E-decision making [29]. A checklist of questions is proposed by Abu-Shanab and Al-Dalou' that measures each of the three stages mentioned [30].

On the other hand, E-government 2.0 seems to be the little child of the web 2.0 influence on how people live, interact, communicate and accomplish their works especially that E-government 2.0 aims to enable public sector, private sector and individuals to work together with government with no existence of intermediaries through using web 2.0 tools in order to use web as a civic platform to achieve social governance, participatory citizenship and electorate intelligence [31]. The employment of such new governance model that utilized web 2.0 capabilities and functionalities will increase the overall effectiveness of public sector and make it more transparent and open [32].
Also, E-government 2.0 will help government in the achievement of its goals with high level of efficiency, effectiveness and democracy in order to increase public awareness and citizens' engagement level through utilizing citizens' feedback about government services, policies and information [33].

\section{The Hashemite Kingdom of Jordan as a Case Study}

\subsection{The Jordanian E-Government Initiative}

Launching the REACH initiative (1999-2005) is considered the starting point of E-government initiative in Jordan; this initiative outlined the situation in Jordan and the goals that Jordan needs to achieve in relation to the Jordanian ICT sector for this period. In 2007, the national ICT sector strategy (2007-2011) was launched and another initiative is expected to be launched for 2012-2016 [34].

The online presence of Jordan started in 2006 when the official website of the Jordanian E-government was launched; the website was launched to be used as a one-stop-shop portal for all government services that are divided into three main categories as they appear on the website homepage. These three main categories are: government to citizen (G2C), government to business (G2B) and government to government $(\mathrm{G} 2 \mathrm{G})$ [35]. The site facilitates one thousand and eight hundred government services that range from tendering, income tax services, industry and trade to civil services, housing and real state are described in the Jordanian E-government website [1]. Jordan's rank in the UN global E-government survey 2012 is shown in Table 1.

\subsection{Jordanian E-government Presence on Facebook}

In order to achieve the goal of this paper, Jordanian e-government fans page on Facebook is taken as a case to show the extent to which governments and citizens interact and communicate with each other using social network which is Facebook in this case. At first, the authors contacted the Ministry of Information and Communication Technologies (MoICT) in Jordan to provide us with several page insights through which we can understand the performance of Jordan e-government Facebook fan page. The Jordanian government joined Facebook on November 16, 2011 to learn more about its audience (most of these insights are taken at the morning of August 7, 2012). The following lines give more insights.

Figure 1 presents four metrics through which we can understand the overall performance of the Jordan e-government Facebook page. The first metric is "Total Likes" which presents the number of unique people who like your page. The second metric is "Friends of Fans" that presents the number of unique people who are friends with the page fans including current fans. The third metric is "People Talking About This" which presents the number of 
unique people who have created a story about the page in the last seven days. The last metric is "Weekly Total Reach" that presents the number of unique people who have seen any content associated with the page in the last seven days (including any related ads or sponsored story).

Figure 2 presents a graph that shows how the posts that are published on the page influence the number of "People Talking About This" metric, and how the number of people talking about the page influences the page overall reach taking into consideration the date shown in the figure. The graph shows a positive relationship.
The following three figures (Figures 3,4 \& 5) assist us in learning more about the page audience in terms of who are the page fans, the people that the page reached and the people who talk about the page. Figure 3 gives information about the page fans in terms of demographic and location. This information is based on the data people enter in their profile. Figure 4 gives information about the people who reach the page and see any content posted on it. Figure 5 gives more information about people who talk about the page in terms of demographic and location.

Table1. Jordan in the UN Global E-Government Development Index 2012

\begin{tabular}{|c|c|c|c|c|c|}
\hline \multicolumn{5}{|c|}{ UN Global E-Government Survey 2012} & UN E-Government Development Index 2012 \\
\hline Rank & Country & Index value & $\begin{array}{c}\text { Online service } \\
\text { component }\end{array}$ & $\begin{array}{c}\text { Telecommunication } \\
\text { infrastructure component }\end{array}$ & $\begin{array}{c}\text { Human capital } \\
\text { component }\end{array}$ \\
\hline 95 & Maldives & 0.4994 & 0.3268 & 0.3599 & 0.8114 \\
\hline 96 & Azerbaijan & 0.4984 & 0.3660 & 0.3033 & 0.8259 \\
\hline 97 & Indonesia & 0.4949 & 0.4967 & 0.2717 & 0.7982 \\
\hline 98 & Jordan & 0.4884 & 0.3922 & 0.1903 & 0.8013 \\
\hline 99 & Kyrgyzstan & 0.4879 & 0.4248 & 0.2638 & 0.7089 \\
\hline 100 & Iran & 0.4876 & 0.4902 & 0.789 \\
\hline
\end{tabular}

(Source: UN Department of Economics and Social Affairs (UNDESA), 2012)

\section{Jordan e-Government Prog... Timeline}

\section{Total Likes? $\quad$ Friends of Fans? People Talking About This? Weekly Total Reach?

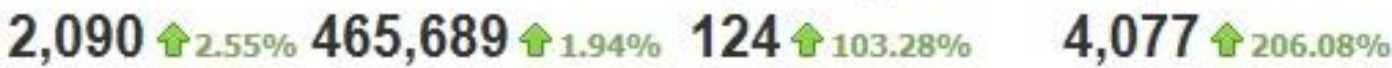

Figure 1. The overall performance of the page

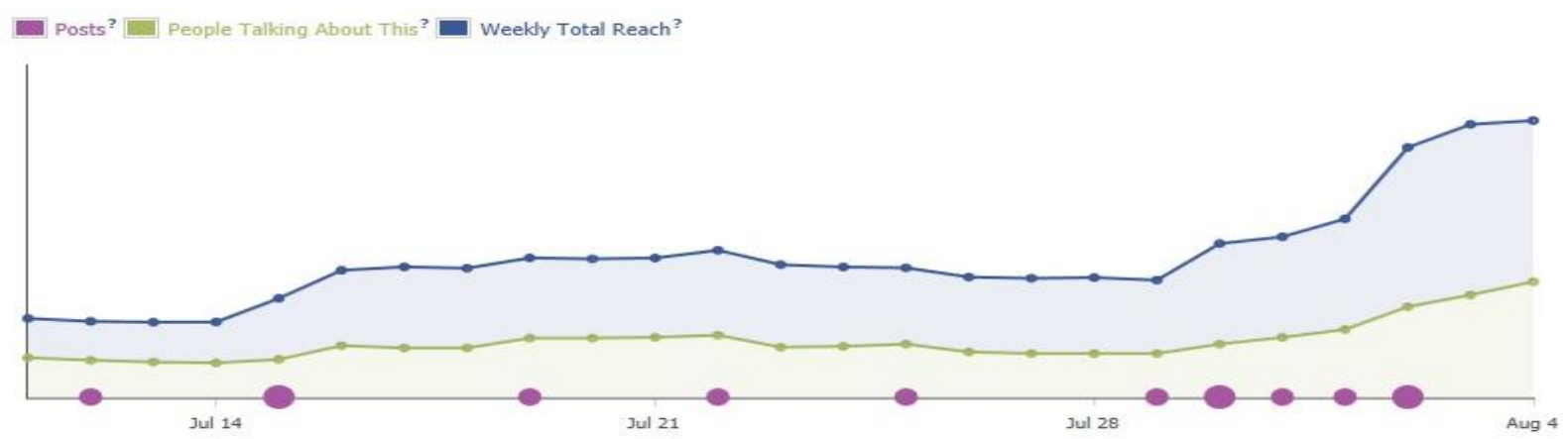


\begin{tabular}{|l|l|}
\hline Jordan e-Government Prog... & Timeline - \\
\hline
\end{tabular}

People Who Like Your Page (Demographics and Location)

Gender and Age?
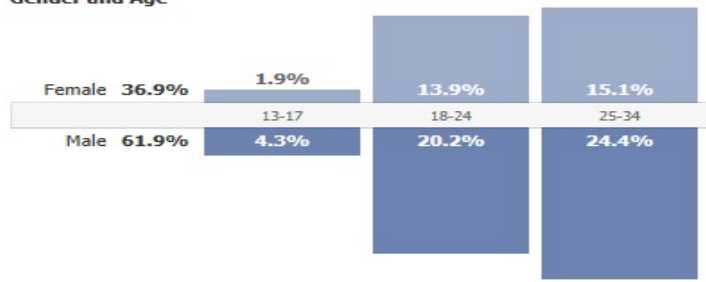

Countries?

1,835 Jordan

50 Saudi Arabia

38 Egypt

27 United Arab Emirates

13 Palestine

12 Serbia

11 United States of America

More-
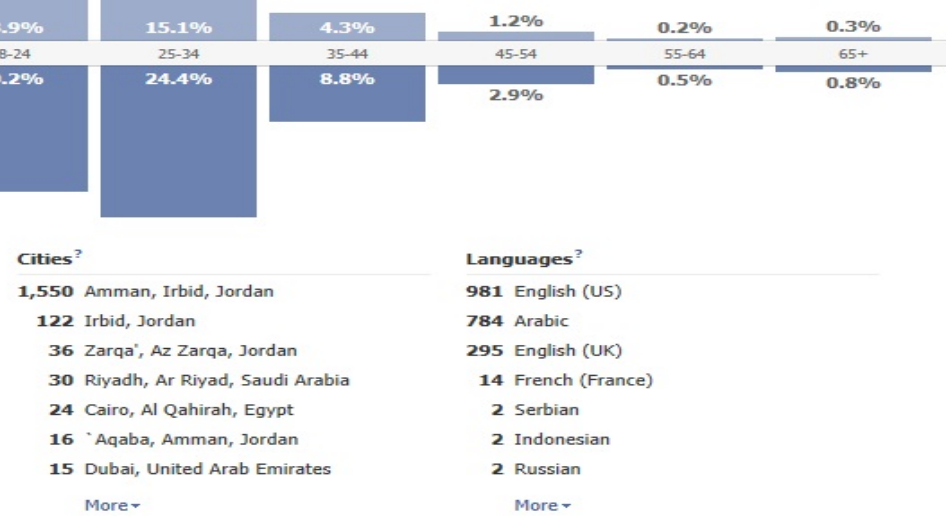
Languages?
981 English (US)
784 Arabic
295 English (UK)
14 French (France)
2 Serbian
2 Indonesian
2 Russian

More -

Figure 3. Page fans in terms of demographic and location

\begin{tabular}{|l|l|}
\hline Jordan e-Government Prog... & Timeline -
\end{tabular}

Who You Reached (Demographics and Location)

Gender and Age?
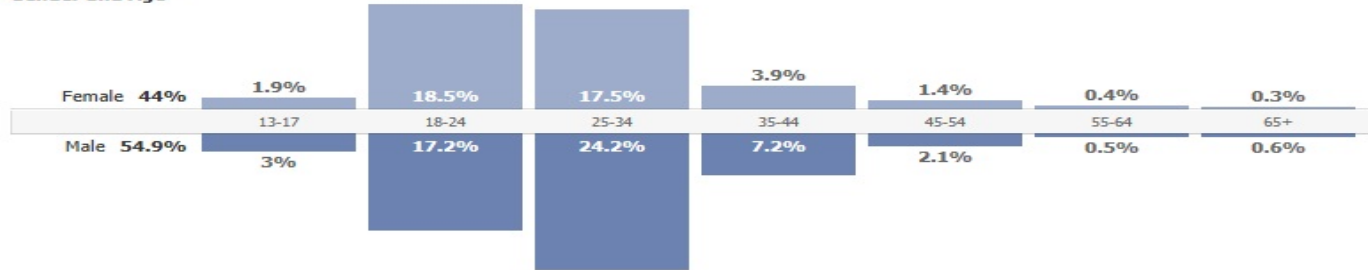

Countries?

Cities?

3,333 Jordan

142 Saudi Arabia

121 United States of America

3,026 Amman, Irbid, Jordan

134 Irbid, Jordan

83 Riyadh, Ar Riyad, Saudi Arabia

58 Dubai, United Arab Emirates

43 Zarqa', Az Zarqa, Jordan

27 Cairo, Al Qahirah, Egypt

43 Palestine

43 Egypt

26 Abu Dhabi, United Arab Emirates

More

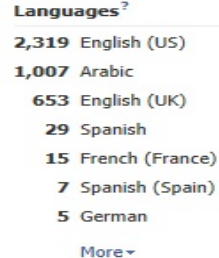

Figure 4. Fans who reached the page in terms of demographic and location

Who Is Talking About Your Page (Demographics and Location)

Gender and Age?
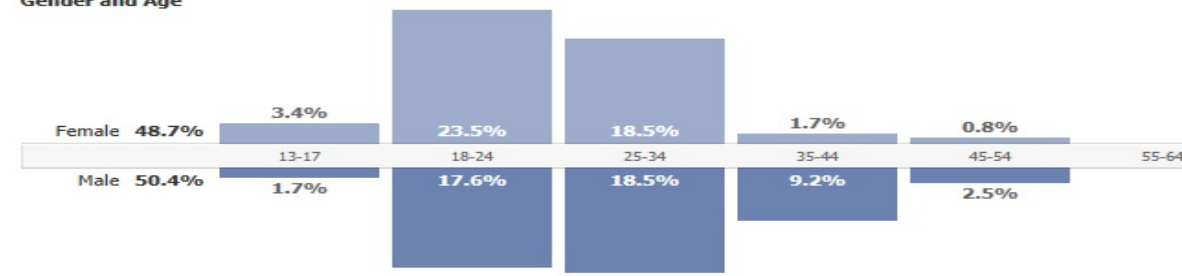

\section{Languages?}

Countries?

Cities?

59 English (US)

106 Jordan

94 Amman, Irbid, Jordan

4 Irbid, Jordan

43 Arabic

2 United Arab Emirates

2 Riyadh, Ar Riyad, Saudi Arabia

16 English (UK)

2 Qatar

2 Zarqa', Az Zarqa, Jordan

1 Spanish

2 Egypt

1 Ireland

2 Dubai, United Arab Emirates

1 Argentin

Figure 5. Fans who talked about the page in terms of demographic and location 
The above three figures indicate that the page fan base is mostly comprised of men with the following percentage: $61.9 \%, 54.9 \%$ and $50.4 \%$ compared with $36.9 \%, 44 \%$ and $48.7 \%$ for women. The following figures (Figure $6 \& 7$ ) show two graphs; the one on the left presents the number of unique people who have created a story about the page during the indicated dates. The second graph on the right presents the number of unique people who saw a story published by a friend about the page during the indicated dates (the story can be a comment, like, share or answering a question). Both graphs show an increase in the number of people who talk about the page and also in a viral reach.

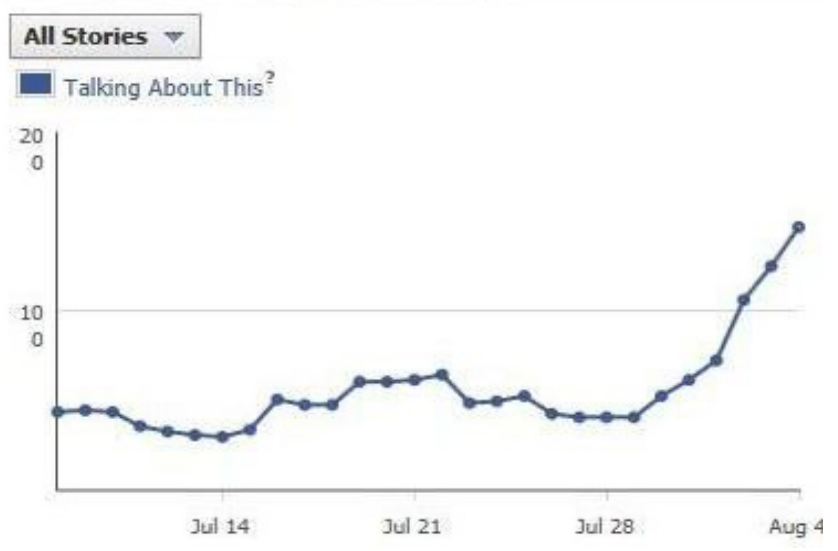

Figure 6. Talking about the page graph

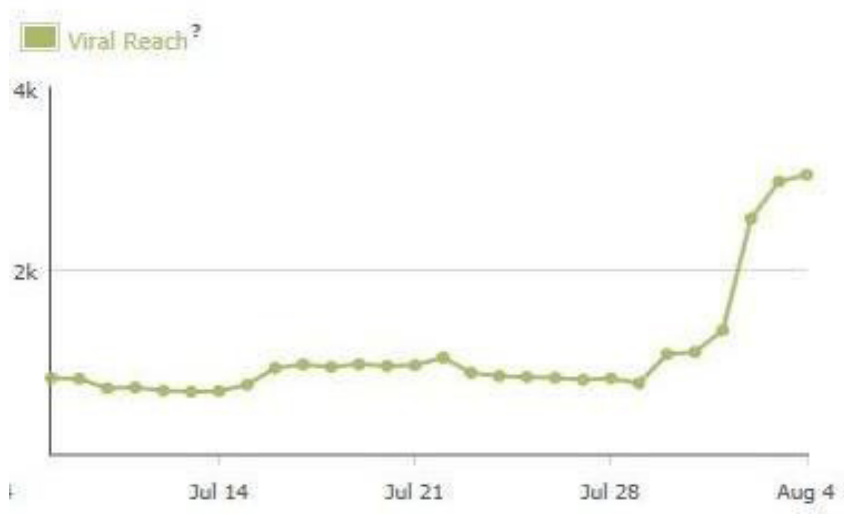

Figure 7. Viral reach graph

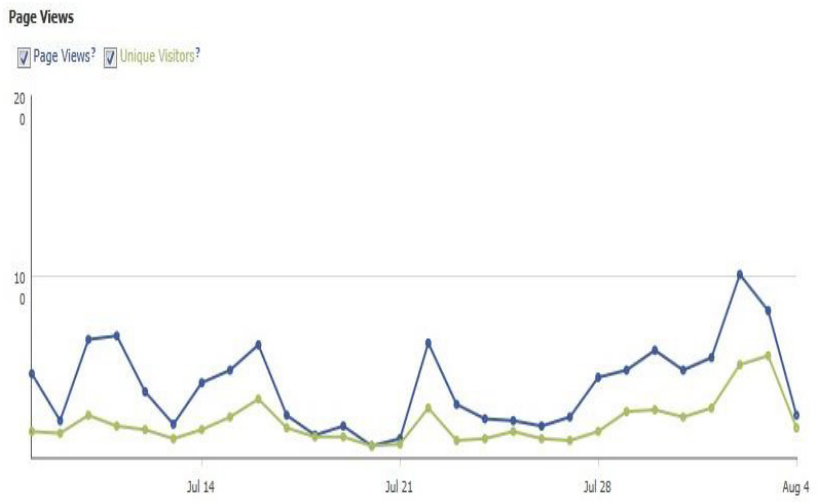

Figure 8. Page views graph
Figure 8 below shows two lines; one for page views and the other for unique visitors. The two lines indicate that the number of page views and unique visitors is wobbling during the indicated dates.

\section{Conclusion}

The growing use of information and communication technologies (ICTs) has a significant impact on how people live, interact and communicate with each other. Such significant impact changes not only the way people perform their work and activities but also the way governments work and perform their functions.

On the other hand, the wide range of available social media tools and sites such as blogs and social networks used by a large number of people and organizations makes e-governments administrators want to think carefully on how they can benefit from joining such sites and using such tools to gain real time engagement with citizens. Such strategic thinking is important to adopt new way of interaction with individuals and to get more insights on citizen's perceptions and opinions in some issues.

In order to achieve the goal of this paper, the Jordan e-government page on Facebook is taken as case study through presenting several page insights which indicates that there is a good level of engagement by citizens, where they interact positively with the posts published by the page through making a like, comment, share, answering a question or just see the page. Also, the insights show that the page fan base is mostly comprised of men between 25 and 34 . It is noticeable that the page views were bumbling for the reported period and better posts effect were shown for the indicated period.

An important issue to consider is that social media tools are new social type of dashboards that aid decision makers in their understanding of how citizens interact with issues posted on the page and how to react to such measures. Finally, a deeper analysis of audience will aid decision makers in targeting specific groups of citizens (young vs. old, male vs. female, employed vs. non-employed,... etc.) and thus addressing their specific needs.

\section{REFERENCES}

[1] Abu-Shanab, E. (2012). Digital Government Adoption in Jordan: An Environmental Model. The International Arab Journal of e-Technology (IAJeT), Vol. 2(3) January 2012, pp. 129-135.

[2] Atari, S., Stewart-Weeks, M. \& McCalla, J. (2011). Web 2.0 in Next-Generation Government and Governance: A Middle East Point of View. Cisco Internet Business Solutions Group (IBSG).

[3] Saulles, M. (2011). Social media and local government in England: who is doing what?. Proceeding of the 11th 
European Conference on e-Government, Ljubljana, Slovenia, June 17.

[4] Harris, A. \& Rea, A. (2009). Web 2.0 and Virtual World technologies: A Growing impact on IS Education. Journal of Information Systems Education, Vol.20 (2).

[5] Bhatnagar, S. (2004). E-government: From Vision to Implementation, Sage Publications, London.

[6] UN E-Government Survey. "E-Government for the people". A survey published by the United Nations Development (2012).

[7] Isbulan, O. (2011). Opinions of University Graduates About Social Networks According To Their Personal Characteristics. TOJET: The Turkish Online Journal of Educational Technology, Vol.10 (2).

[8] Jabbour, K. (2011). WEB 2.0 Technology Tools For Global Education In Lebanon. (IJAEST) International Journal of Advanced Engineering Sciences and Technologies, Vol.7 (1), pp.151-168.

[9] Murthy, C., Rahman, M., Bedajit, O. \& Das, R. (2011). Mediating Through WEB 2.0 --- Imperatives of an End User Perspectives of Websites of Universities of North East Of India. Global Media Journal, Indian Edition, Summer Issue.

[10] Plomp, M. \& Velde, R. (2011). Web 2.0 as a Megatrend in eGovernment: An Empirical Analysis of its Preconditions and Outcomes. European Journal of ePractice, vol.12.

[11] Nica, M. \& Grayson, M. (2011). Effects of Teaching Business Web 2.0 Style. International Journal of Business and Social Science, Vol. 2(18).

[12] Elefant, C. (2011). The "Power" of Social Media: Legal Issues \& Best Practices For Utilities Engaging Social Media. Energy Law Journal, Vol.32 (1).

[13] Landsbergen, D. (2010). Government as Part of the Revolution: Using Social Media to Achieve Public Goals. Electronic Journal of e-Government, Vol. 8(2), pp.135-147.

[14] Lacho, K. \& Marinello, C. (2010). How Small Business Owners Can Use Social Networking To Promote Their Business. The Entrepreneurial Executive, Vol.15, pp. 127-133.

[15] Phulari, S., Khamitkar, S., Deshmukh, N., Bhalchandra, P., Lokhande, S. \& Shinde, A. (2010). Understanding Formulation of Social Capital in Online Social Network Sites (SNS). IJCSI International Journal of Computer Science Issues, Vol.7(1), pp.92-96.

[16] Das, B. \& Sahoo, J. (2011). Social Networking Sites - A Critical Analysis of Its Impact on Personal and Social Life. International Journal of Business and Social Science, Vol. 2(14), pp.222-228.

[17] Pegoraro, A. (2010). Look Who's Talking-Athletes on Twitter: A Case Study. International Journal of Sport Communication, issue 3, pp.501-514

[18] Bulearca, M. \& Bulearca S. (2010). Twitter: a viable marketing tool for SMEs?. Global business and management research, vol.2 (4), pp.296-309.

[19] Griffith, H. (2012). Understanding and Authenticating Evidence From Social Networking Sites. Washington Journal of Law, Technology \& Arts, Vol.7(3), pp.209-224.

[20] Urista, M., Dong, Q. \& Day, K. (2008). Explaining Why
Young Adults Use MySpace and Facebook Through Uses and Gratifications Theory. Human Communication. A Publication of the Pacific and Asian Communication Association, Vol.12(2), pp.215-229.

[21] Shafie, L., Mansor, M., Osman, N., Nayan, S. \& Maesin, A. (2011). Privacy, Trust And Social Network Sites of University Students in Malaysia. Research Journal of International Studies, Issue 20, pp.154-162.

[22] Almarabeh, T. \& AbuAli, A. (2010). A General Framework for E-Government: Definition Maturity Challenges, Opportunities, and Success. European Journal of Scientific Research, vol.39 (1), pp.29-42.

[23] Riad, A., El-Bakry, H. \& El-Adl, G. (2010). A Novel DSS Framework for E-government. IJCSI International Journal of Computer Science Issues, Vol.7 (6), pp.33-37.

[24] Sandsmark, F. (2011). From Social Media to Social Commerce. Proceeding of Microsoft Global High Tech Summit.

[25] Richards, R. (2010). Digital Citizenship and Web 2.0 Tools. MERLOT Journal of Online Learning and Teaching, Vol.6(2), pp.516-522.

[26] Abdallah, S. \& Khalil, A. (2009). Web 2.0 And E-Governments: An Exploration Of Potentials \& Realities In The Arab World. Proceeding of European and Mediterranean Conference on Information Systems (EMCIS2009), Crowne Plaza Hotel, Izmir, July 13-14.

[27] Kuzma, J. (2010). Asian Government Usage of Web 2.0 Social Media. European Journal of ePractice, issue 9.

[28] Chun, S., Shulman, S., Sandoval, R. \& Hovy, E. (2010). Government 2.0: Making connections between citizens, data and government. Information Polity, vol.15, pp.1-9.

[29] Joseph, R. (2009). A Theoretical Framework for Government 2.0 in Developing and Emerging Economies. Issues in Information Systems, vol.10(2), pp.349-354.

[30] Abu-Shanab E. \& Al-Dalou', R. (2012). E-participation Initiatives: A Framework for Technical Tools, Accepted and will be presented in the 2012 International Arab Conference of e-Technology (IACe-T'2012), ), Zarqa, Jordan, April 25-27, 2012, pp. 57-64.

[31] Mohamed, F., Muthaiyah, S. \& Nassirtoussi, A. (2011). TM: A Development Technique for E-government 2.0 Portals. WSEAS TRANSACTIONS On INFORMATION SCIENCE and APPLICATIONS, vol.8(2), pp.96-108.

[32] Drogkaris, P., Gritzalis, S. \& Lambrinoudakis, C. (2010). Transforming the Greek e-Government Environment towards the e-Gov 2.0 Era. Proceeding of EGOVIS'10 Proceeding of the First international conference on Electronic government and the information systems perspective, pp. 142-149.

[33] Nam, T. (2011). Toward The New Phase of E-Government: An Empirical Study on Citizens' Attitude about Open Government And Government 2.0. Proceeding of The 11th Public Management Research Conference, June 2-4.

[34] Ottoum, I. \& Suleiman, R. (2011). E-Government - The Jordanian Experience. Proceeding of The 5th International Conference on Information Technology, Amman, Jordan, may 11-13.

[35] Abu-Shanab, E. A. \& Abu Baker, A. N. (2011). Evaluating Jordan's e-government website: a case study, Electronic Government, an International Journal, Vol.8(1), pp. 271-289. 